\title{
Macroeconomic Determinants of Cryptocurrency Volatility: Time Series Analysis
}

\author{
Dilek Teker \\ Department of Business \\ Isık University, Sile Campus \\ Istanbul, Turkey \\ Suat Teker \\ Department of Economics \\ Isık University, Sile Campus \\ Istanbul, Turkey \\ Mustafa Ozyesil \\ Department of Business Administration \\ Istanbul Aydin University \\ Istanbul, Turkey
}

\begin{abstract}
Cryptocurrency is a recent and popular topic that attracts the interest of investors and fund managers. Beyond the market discipline, researchers question the interaction between cryptocurrencies and macroeconomic variables. This study focuses on how the changes in gold and oil prices affect the daily price movements of various cryptocurrencies. The daily database used in this study includes the prices of the cryptocurrencies such as Bitcoin, Tether, Ethereum, Litecon and EOS for the period of August 1, 2017 and April 3, 2019. Initially, the stationarity of the time series is tested by $\mathrm{Ng}$ and Perron (2001) method. The existence of the cointegration relationship among the series is tested by Johansen (1988) technique. The presence of causality relationships among the series is investigated with the Dolado and Lütkepohl (1996) causality test. The empirical results support that there exists a cointegration relationship only in between Tether and gold and oil prices.
\end{abstract}

Keywords: Cryptocurrencies, stationarity, cointegration, vector error correction model, fiat currencies.

\section{Introduction}

Cryptocurrencies are digital, virtual and alternative currencies to what we have been using over hundreds of years. Cryptocurrencies are decentralized, unlike those in central electronic currencies and banking systems. The control of this decentralized structure is also carried out by block-chain transaction databases. The exponential growth of cryptocurrency market in the last a few years has become a phenomenon grabbing the attention of many researchers. There currently exists 2818 various cryptocurrencies in the literature. The most well-known of these may be identified as Bitcoin (BTC), Litecoin (LTC), Ethereum (ETH), Ripple (XRP), Bitcoin Cash (BCH), Ethereum Classic (ETC). Among the others, Bitcoin possesses the highest market value and has registered a number of sharp increases in its unit price in the very recent years. The cryptocurrency market may be called as a considerable fresh market. Bitcoin was first created in 2009 and started to actively trading in 2013. Cryptocurrencies are fairly different from the other fiat currencies. A fiat currency is backed by the full credit of its government. The issuance of a fiat currency is supervised by the nation's central bank. On the other hand, the value of a Bitcoin is determined by how much the investors are willing to pay for it. Moreover, there is no government backup for cryptocurrencies. A number of academic studies has worked on explaining the price movements of cryptocurrencies and the economic factors affecting the volatility of their prices. Most studies employed Bitcoin as the dependent variable and some other studies compared the price performance of Bitcoin to other cryptocurrencies. Several factors affecting cryptocurrency prices have been identified in the previous literature. Buchholz et al. (2012), and Bouoiyour and Selmi (2015) propose the supply and demand of digital currencies as the relevant factors. Kristoufek (2013), and Bouoiyour and Selmi (2015) point that the attractiveness to investors acts as a strong determinant. Furthermore, Van Wijk (2013) determines a number of global macro-financial developments affecting the market prices. The researches of Cheung et al. (2015), Dwyer (2014), Bouoiyour and Selmi (2015) and Carrick (2016) highlight that the cryptocurrency market is much more volatile among the other types of financial markets. Table 1 indicates the market-cap, trading volume and ranking for the most popular cryptocurrencies as of December, 2019. 
Table 1. Ranking Comparisons of the First 10 Cryptocurrencies

\begin{tabular}{|c|c|c|c|c|c|}
\hline \multirow[b]{2}{*}{ Cryptocurrency } & \multicolumn{2}{|c|}{ Market Cap } & \multicolumn{2}{|c|}{ Total Volume } & \multirow[b]{2}{*}{$\begin{array}{l}\text { Unit Price } \\
\text { (USD) }\end{array}$} \\
\hline & $\begin{array}{l}\text { Value (billion } \\
\text { USD) }\end{array}$ & Rank & $(\%)$ & Rank & \\
\hline Bitcoin & 167.32 & 1 & 29 & 2 & 9546.5 \\
\hline Ethereum & 19.50 & 2 & 10 & 3 & 184.07 \\
\hline Ripple & 12.59 & 3 & 2 & 7 & 0.29543 \\
\hline Bitcoin Cash & 4.61 & 4 & 3 & 5 & 258.23 \\
\hline Tether & 4.06 & 5 & 37 & 1 & 1.0035 \\
\hline Litecoin & 3.61 & 6 & 4 & 4 & 57.353 \\
\hline EOS & 2.96 & 7 & 3 & 6 & 3.1697 \\
\hline Binance Coin & 2.93 & 8 & 0,2 & 18 & 18.8916 \\
\hline Bitcoin SV & 2.55 & 9 & 0,9 & 9 & 140.81 \\
\hline Stellar & 1.25 & 10 & 0.3 & 15 & 0.06274 \\
\hline
\end{tabular}

Source: investing.com

Bouoiyour et al. (2015) identifies Bitcoin as one of the most innovative financial tool as many other researchers. Bouoiyour and Selmi (2015) criticizes Bitcoin because of its unpredictable volatility in the market. Since Bitcoin is generally observed as highly volatile; it is more susceptible to speculative bubbles than other currencies (Grinberg, 2011). Hence, Bitcoin has a good popularity in the financial markets and in portfolio management practices (Dyhrberg, 2016). Roy et all (2018) uses autoregressive integrated moving average (ARIMA) models to explain Bitcoin volatility. Katsiampa (2017) explores the optimal conditional heteroscedasticity model with regards to goodness-of-fit to Bitcoin price data using AR-GARCH, AR-EGARCH, AR-TGARCH, AR-APARCH, AR-CGARCH, AR-ACGARCH models. The empirical results indicate AR-CGARCH model as a better model explaining its volatility. Stavroyiannis and Babalos (2017) uses univariate and multivariate GARCH models and vector autoregressive specifications to explain the dynamics of Bitcoin. Cermak (2017) uses a GARCH $(1,1)$ to model Bitcoin's volatility movements with regard to several macroeconomic indicators. He targets the countries where Bitcoin has a high trading volume. Chen et al. (2016) tests various versions of GARCH models to predict its volatility. Based on information criterion such as AIC and BIC, TGARCH $(1,1)$ model is supported as an optimal model. Naimy and Hayek (2018) compares the predictive ability of volatility forecasts estimated by GARCH and EGARCH models. According to their findings, the EGARCH $(1,1)$ model outperforms the GARCH $(1,1)$ and EWMA models in terms of both sample and out of sample contexts with an increased accuracy in the out of sample period. Chu et al. (2017) fits 12 GARCH-type models to seven major cryptocurrencies. El Bahrawy and Alessandretti (2017) examines the behaviour of 1469 cryptocurrencies in the period of April 2013 and May 2017. They find out that the cryptocurrencies continuously appear and disappear while their market capitalization have exponentially been increasing. Poyser (2017) explains the external and internal indicators affecting the movements of cryptocurrencies. These indicators mainly are the popularity and legalization as internal factors while the interest rates, stock markets and gold prices as external factors.

\section{Data \& Methodology}

In this study, it is investigated whether Bitcoin, Tether, Ethereum, Litecoin and EOS are becoming investment alternatives for the Turkish investors. The daily prices, volumes and returns for the underlying cryptocurrencies are utilized for the period of August 1, 2017 and April 3, 2019. The data sets are acquired through the public web pages of investing.com. In this study, the prices of crypto currencies in USD are used as the dependent variables while the ounce price of gold in USD and the barrel price of Brent Oil in USD are used as the independent variables. Cryptocurrencies and gold are traded in the free markets while oil is traded in the Futures Options Market (VIOP). The logarithmic transformation was applied to all data to prevent heteroscedasticity and volatility problems. The descriptive statistics for 484 observations are presented in Table 2 below. 
Table 2: Descriptive Statistics of the Data Set

\begin{tabular}{|c|c|c|c|c|c|c|c|}
\hline $\begin{array}{c}\text { Statistics of } \\
\text { Data }\end{array}$ & LnBIT & LnTET & LnETH & LnLIT & LnEOS & LnGOLD & LnOIL \\
\hline Average & 8.73 & 0.69 & 5.74 & 4.29 & 1.44 & 7.16 & 4.16 \\
\hline Median & 8.78 & 0.69 & 5.70 & 4.11 & 1.64 & 7.16 & 4.18 \\
\hline Maximum & 9.86 & 0.73 & 7.22 & 5.88 & 3.07 & 7.25 & 4.45 \\
\hline Minimum & 7.90 & 0.68 & 4.44 & 3.16 & -0.71 & 7.08 & 3.80 \\
\hline $\begin{array}{c}\text { Standard } \\
\text { Deviation }\end{array}$ & 0.42 & 0.00 & 0.68 & 0.61 & 0.87 & 0.04 & 0.15 \\
\hline Skewness & 0.35 & 1.17 & 0.06 & 0.52 & -0.67 & 0.02 & -0.37 \\
\hline Kurtosis & 2.59 & 11.46 & 2.02 & 2.47 & 2.85 & 2.15 & 2.23 \\
\hline Jarque-Bera & 13.06 & 1553.18 & 19.73 & 27.58 & 36.70 & 14.76 & 23.27 \\
\hline Probability & 0.00 & 0.00 & 0.00 & 0.00 & 0.00 & 0.00 & 0.00 \\
\hline $\begin{array}{c}\text { Total } \\
\text { Sum of }\end{array}$ & 8225.13 & 335.98 & 2776.13 & 2078.68 & 695.34 & 3465.70 & 2015.39 \\
\hline $\begin{array}{c}\text { Squares of } \\
\text { Deviations }\end{array}$ & 84.64 & 0.01 & 225.36 & 182.57 & 366.15 & 0.66 & 11.48 \\
\hline $\begin{array}{c}\text { Number of } \\
\text { Observations }\end{array}$ & 484 & 484 & 484 & 484 & 484 & 484 & 484 \\
\hline
\end{tabular}

In this study, the relationships in between the returns of cryptocurrencies, gold and oil are analyzed through the Equation (1) based on Sarkaya Icellioglu and Engin Ozturk (2018), Cutcu and Kilic (2018), Gulec, Cevik and Bahadir (2018), Ozturk et al. (2018) and Kesebilir and Gunceler (2019). As indicated in equations below natural logarithms of the data are employed.

$$
\begin{aligned}
& \operatorname{LnBIT}_{t}=\beta_{0}+\beta_{2} \text { LnGOLD }_{\mathrm{t}}+\beta_{\mathrm{a}} \text { LnOIL }_{\mathrm{t}}+u_{\mathrm{t}} \\
& \text { LnTET }_{\mathrm{t}}=\alpha_{0}+\alpha_{2} \text { LnGOLD }_{\mathrm{t}}+\alpha_{\mathrm{a}} \text { LnOIL }_{\mathrm{t}}+v_{\mathrm{t}} \\
& \text { LnETH }_{\mathrm{t}}=\gamma_{0}+\gamma_{2} \text { LnGOLD }_{\mathrm{t}}+\gamma_{\mathrm{a}} \text { LnOIL }_{\mathrm{t}}+e_{\mathrm{t}} \\
& \text { LnLIT }_{\mathrm{t}}=\theta_{0}+\theta_{2} \text { LnGOLD }_{\mathrm{t}}+\theta_{\mathrm{a}} \text { LnOIL }_{\mathrm{t}}+\varepsilon_{\mathrm{t}} \\
& \text { LnEOS }_{\mathrm{t}}=\delta_{0}+\delta_{2} \text { LnGOLD }_{\mathrm{t}}+\delta_{\mathrm{a}} \text { LnOIL }_{\mathrm{t}}+\varepsilon_{\mathrm{t}}
\end{aligned}
$$

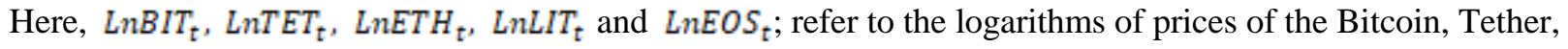

Ethereum, Litecoin and EOS respectively. $\operatorname{LnGOLD_{t}}$ represents the logarithm of the selling price of ounce of gold while ${ }_{n n P E T}$ indicates the logarithm of the salling price of crude oil. $u_{\mathrm{t}}, v_{\mathrm{t}}, e_{\mathrm{t}}, \varepsilon_{\mathrm{t}}$ and $\varepsilon_{\mathrm{t}}$; show the series of error terms with a white noise process. Table 3 indicates correlation matrix for variables used in this study.

Table 3. Correlation Matrix

\begin{tabular}{|l|c|c|c|c|c|c|c|}
\hline & LnBIT & LnTET & LnETH & LnLIT & LnEOS & LnGOLD & LnOIL \\
\hline LnBIT & 1 & -0.02 & 0.84 & 0.89 & 0.63 & 0.26 & 0.14 \\
\hline LnTET & -0.02 & 1 & -0.08 & 0.02 & -0.08 & 0.08 & -0.32 \\
\hline LnETH & 0.84 & -0.08 & 1 & 0.92 & 0.53 & 0.43 & -0.09 \\
\hline LnLIT & 0.89 & 0.02 & 0.92 & 1 & 0.63 & 0.47 & -0.02 \\
\hline LnEOS & 0.63 & -0.08 & 0.53 & 0.63 & 1 & 0.35 & 0.62 \\
\hline LnGOLD & 0.26 & 0.08 & 0.43 & 0.47 & 0.35 & 1 & -0.03 \\
\hline LnOIL & 0.14 & -0.32 & -0.09 & -0.02 & 0.62 & -0.03 & 1 \\
\hline
\end{tabular}

According to the results in this table, there is a positive but weak relationship in between Bitcoin and gold (0.26), and Bitcoin and oil (0.14). Tether and gold (0.08) show a positive but a weak relationship. Tether and oil (-0.32) have a 
negative and a relatively weak relationship. There looks a positive and a relatively strong relation in between Ethereum and gold (0.43) while there looks a negative but a relatively weak relationship in between Ethereum and oil (-0.09). There is a positive and a relatively strong relation in between Litecoin and gold (0.47) and there is a negative but a relatively weak relation in between Litecoin and oil (-0.02). There is a positive and a relatively strong relationship in between EOS and gold (0.35) and oil (0.62). As an initial step, the cointegration test is performed to determine the long-term relation in between the returns of the cryptocurrencies and the returns of gold and oil. When interpreting the results of the regression analysis, the following way will be applied. For example, if $\beta_{1}$ will be lower than $0\left(\beta_{1}<0\right)$, then the cryptocurrency is a substitution of gold. If the result is $\beta_{1}>0$, then the cryptocurrency is a complement to the gold. if $\beta_{1}$ is statistically insignificant, then the cryptocurrencies are not alternative investment instruments for gold. A similar analysis is used to explain the relationships in between the other cryptocurrencies and oil. The stationarity of the series is tested with $\mathrm{Ng}$ and Perron (2001) method and the existence of the cointegration relationship among the series is examined through Johansen (1988) method. The long-term and the short-term analyzes are carried out by using the VEC method and finally the presence of causality relationships among the series is investigated by Dolado and Lütkepohl (1996) causality test.

\section{Empirical Results}

\subsection{Unit Root Tests}

The degree of stationarity of the series is very important in time series analysis. The faulted results may be obtained if the models are applied without considering the stationarity degrees of the series (Elder and Kennedy, 2001). For this reason, it is useful to first determine the degree of stationarity of the series and then select the method accordingly. In this study, the stationarity of the series is tested with $\mathrm{Ng}$ and Perron (2001) method. This test is especially developed to correct the problem of size distortion in the volume of error term in Phillips and Perron (1988) test. This method is preferred in the study because it is more powerful than ADF and PP tests (Charles, Darne and Tripier, 2018). Ng and Perron (2001) developed four different test statistics in this method as follows.

$$
\begin{aligned}
& M Z_{\alpha}=\left(T^{-1}\left(Y_{T}^{D}\right)^{2}-f_{0}\right) /(2 K) \\
& M Z_{\mathrm{t}}=M Z_{\alpha} x M S B \\
& M S B=\left(\frac{f^{\frac{1}{2}}}{f_{0}}\right. \\
& M P T= \begin{cases}\frac{\left(\bar{c}^{2} K-\bar{c} T^{-1}\left(Y_{T}^{D}\right)^{2}\right)}{f_{0}} & \text { if } x_{\mathrm{t}}=\{1\} \\
\frac{\left(\bar{c}^{2} K+(1-\bar{c}) T^{-1}\left(Y_{T}^{d}\right)^{2}\right)}{f_{0}} & \text { if } x_{\mathrm{t}}=\{1, t\}\end{cases}
\end{aligned}
$$

Here $T_{i}$ refers to time dimension, $Y_{T}^{D}$; shows the trend-free series, $f_{0}$; refers to the zero-spectrum frequency estimation function.

$$
\begin{gathered}
K=\sum_{\mathrm{t}=2}^{T} \frac{\left(Y_{t-1}^{d}\right)^{2}}{T^{2}} \\
c=\left\{\begin{array}{cc}
-7 & \text { if } x_{\mathrm{t}}=\{1\} \\
-13.5 & \text { if } x_{\mathrm{t}}=\{1, t\}
\end{array}\right.
\end{gathered}
$$


Table 4: Unit Root Test Results

\begin{tabular}{|c|c|c|c|c|c|c|c|c|}
\hline & \multicolumn{4}{|c|}{ Level Values } & \multicolumn{4}{|c|}{ First Difference } \\
\hline & $\mathbf{M Z}_{\alpha}$ & $\mathrm{MZ}_{\mathrm{t}}$ & MSB & MPT & $\mathrm{MZ}_{\alpha}$ & $\mathrm{Mz}_{\mathrm{t}}$ & MSB & MPT \\
\hline LnBIT & -3.12 & -1.21 & 0.39 & 28.49 & $166.16^{-} * *$ & $-9.05 * * *$ & $0.05 * * *$ & $0.23 * * *$ \\
\hline LnTET & -16.63 & -2.04 & 0.41 & 5.55 & $\begin{array}{c}- \\
206.34^{* * *} \\
\end{array}$ & $\begin{array}{c}- \\
10.13^{* * * *} \\
\end{array}$ & $0.04 * * *$ & $0.14 * * *$ \\
\hline LnETH & -1.47 & -0.83 & 0.56 & 58.94 & $\begin{array}{c}- \\
219.23^{* * *} \\
\end{array}$ & $\begin{array}{c}- \\
10.44 * * * \\
\end{array}$ & $0.04 * * *$ & $0.15 * * *$ \\
\hline LNLIT & -3.41 & -1.30 & 0.38 & 26.67 & $165.45^{* * * *}$ & $-9.05 * * *$ & $0.05 * * *$ & $0.21 * * *$ \\
\hline LnEOS & -2.35 & -1.07 & 0.45 & 38.13 & $\begin{array}{c}- \\
285.19^{* * *} \\
\end{array}$ & $\frac{-}{-}$ & $0.04 * * *$ & $0.13 * * *$ \\
\hline LnGOL & -4.65 & -1.52 & 0.32 & 19.59 & $-68.26 * * *$ & $-5.83 * * *$ & $0.08 * * *$ & $0.37 * * *$ \\
\hline LnOIL & -3.52 & -1.26 & 0.35 & 24.83 & $\begin{array}{c}- \\
166.59 * * *\end{array}$ & $-9.12 * * *$ & $0.05 * * *$ & $0.15^{* * *}$ \\
\hline \multicolumn{9}{|c|}{ Critical Values } \\
\hline & $\mathbf{M Z}_{\alpha}$ & $\mathrm{MZ}_{\mathrm{t}}$ & MSB & MPT & $\mathrm{MZ}_{\alpha}$ & $\mathrm{Mz}_{\mathrm{t}}$ & MSB & MPT \\
\hline$\% 1$ & -23.80 & -3.42 & 0.14 & 4.03 & -13.80 & -2.58 & 0.17 & 1.78 \\
\hline$\% 5$ & -17.30 & -2.91 & 0.16 & 5.48 & -8.10 & -1.98 & 0.23 & 3.17 \\
\hline
\end{tabular}

Note: $* * *$ indicates that the series is stationary at $1 \%$ significance level. Optimal delay lengths are determined according to the modified Akaike criteria. Tests with constant terms and trend are used for the level values of the series and only fixed terms test methods are used for the first differences.

As seeing on Table 2, while the series are not stationary in the tests performed for the level values, all series become stationary after taking their first differences. This type of econometric series is called I(1) series (Dikmen, 2012: 308311). In this case, during the analysis period, it can be said that there are significant fluctuations in the prices of crypto currencies, gold and oil. Appendix 1 and Appendix 2 indicate the graphs of the series for raw data, natural logarithm and first differenced data. It is clearly observed all series incur root and differencing method should be used. Since the series are not stationary in level values, according to Granger and Newbold (1974), spurious regression problem may be encountered in the analysis with the level values of the series. According to Engle and Granger (1987), cointegration testing should be performed in such cases. When the cointegration relationship is determined among the series in the models, it is decided that the series move together in the long term and the series values will not be confronted with spurious regression analysis (Hubrich, Lutkepohl and Saikonen, 2001). Therefore, it is decided to investigate the existence of the cointegration relationship between the series in the models.

\subsection{Cointegration Test}

Since all series are tested to be I(1), the existence of cointegration relationship between the series can be tested by Engle and Granger (1987) or Johansen (1988) method (Tar1, 2012: 415-432). Engle and Granger (1987) method gives effective results in models with single explanatory variables while Johansen (1988) method should be used in models with multiple explanatory variables (Kremers, Ericsson and Dolado, 1992). Johansen (1988) $H_{0}$ hypothesis of the cointegration test "There is no cointegration relationship among the series". To perform the Johansen (1988) cointegration test, a standard (unrestricted) VAR model must be estimated and the optimum lag length must be determined. It is also important that there is no autocorrelation and heteroscedasticity problems in VAR model with determined lag length. The optimal lag length determination results in this study are shown in Table 5. The graphs of inverse characteristic roots indicating that the VAR models with the determined optimum lag length are stable presented in Appendix 2. It may be seen in these graphs that the inverse characteristic roots remain within the unit circle. This shows that the established models (VAR models with optimum lag length) are stable and the VEC, the Johansen cointegration test and the causality analysis based on these VAR models are reliable. 
Table 5: Optimum Lag Length Determination Process Results

\begin{tabular}{|c|c|c|c|c|c|}
\hline \multirow{2}{*}{$\begin{array}{c}\text { The } \\
\text { dependent } \\
\text { variable }\end{array}$} & \multirow{2}{*}{$\begin{array}{c}\text { Optimum } \\
\text { Lag } \\
\text { Length }\end{array}$} & \multicolumn{2}{|c|}{$\begin{array}{c}\text { Autocorrelation Test Result } \\
\text { Statistics }\end{array}$} & $\begin{array}{c}\text { Probability } \\
\text { Value }\end{array}$ & $\begin{array}{c}\text { Testerst } \\
\text { Result }\end{array}$ \\
\cline { 3 - 6 } & Statistics & $\begin{array}{c}\text { Probability } \\
\text { Value }\end{array}$ \\
\hline LnBIT & 2 & 14.02 & 0.12 & 185.25 & 0.15 \\
\hline LnTET & 4 & 11.39 & 0.24 & 235.85 & 0.25 \\
\hline LnETH & 2 & 14.84 & 0.09 & 190.65 & 0.18 \\
\hline LnLIT & 2 & 28.32 & 0.05 & 209.68 & 0.84 \\
\hline LnEOS & 2 & 22.23 & 0.22 & 191.23 & 0.27 \\
\hline
\end{tabular}

In this part, the Johansen (1988) cointegration test is performed separately for each cryptocurrency model using the optimum lag lengths appearing in Table 4 and the results are presented in Table 6.

Table 6: Cointegration Test Results

\begin{tabular}{|c|c|c|c|c|c|c|}
\hline $\begin{array}{c}\text { The } \\
\text { dependent } \\
\text { variable }\end{array}$ & $\begin{array}{c}H_{0} \\
\text { Hypothesis }\end{array}$ & $\begin{array}{r}\text { Trace } \\
\text { Statistics }\end{array}$ & $\begin{array}{r}\text { Probabi } \\
\text { lity Value }\end{array}$ & $\begin{array}{c}\text { Max-Eigen } \\
\text { Value Statistics }\end{array}$ & $\begin{array}{r}\text { Probab } \\
\text { ility Value }\end{array}$ & Decision \\
\hline \multirow{3}{*}{ BITCOIN } & None & 22.15 & 0.58 & 9.57 & 0.86 & \multirow{3}{*}{$\begin{array}{c}\text { No } \\
\text { Cointegration }\end{array}$} \\
\hline & Up to 1 & 12.58 & 0.39 & 8.14 & 0.53 & \\
\hline & Up to 2 & 4.44 & 0.35 & 4.44 & 0.35 & \\
\hline \multirow{3}{*}{ TETHER } & None & $31.72 * *$ & 0.02 & $22.62 * *$ & 0.03 & \multirow{3}{*}{ Cointegration } \\
\hline & Up to 1 & 9.09 & 0.35 & 5.90 & 0.62 & \\
\hline & Up to 2 & 3.19 & 0.17 & 3.19 & 0.17 & \\
\hline \multirow{3}{*}{$\begin{array}{l}\text { ETHEREU } \\
{ }_{M}\end{array}$} & None & 20.05 & 0.41 & 9.44 & 0.79 & \multirow{3}{*}{$\begin{array}{c}\text { No } \\
\text { Cointegration }\end{array}$} \\
\hline & Up to 1 & 10.60 & 0.23 & 7.60 & 0.41 & \\
\hline & Up to 2 & 2.99 & 0.18 & 2.99 & 0.18 & \\
\hline \multirow{3}{*}{ LITECOIN } & None & 20.93 & 0.66 & 8.39 & 0.93 & \multirow{3}{*}{$\begin{array}{c}\text { No } \\
\text { Cointegration }\end{array}$} \\
\hline & Up to 1 & 12.54 & 0.40 & 7.36 & 0.62 & \\
\hline & Up to 2 & 5.18 & 0.26 & 5.18 & 0.26 & \\
\hline \multirow{3}{*}{ EOS } & None & 20.59 & 0.38 & 11.26 & 0.62 & \multirow{3}{*}{$\begin{array}{c}\text { No } \\
\text { Cointegration }\end{array}$} \\
\hline & Up to 1 & 9.33 & 0.33 & 6.34 & 0.56 & \\
\hline & Up to 2 & 2.98 & 0.18 & 2.98 & 0.18 & \\
\hline
\end{tabular}

Note: $* *$ indicates the presence of cointegration at the $5 \%$ significance level in the relevant model.

When the test results in Table 6 are examined, it is seen that there is a cointegration relationship at 5\% significance level only for Tether. No other cointegration is detected for the other cryptocurrencies. In this case, the analysis with the level values of the series in the model where only the dependent variable is Tether will not include spurious regression problem and be reliable. Therefore, only long and short term analysis are performed for this model.

\subsection{Long and Short Term Results}

In cases where the cointegration relationship among the series is examined by the Johansen (1988) test, the long and the short term analysis are performed with the help of Vector Error Correction (VEC) method (Heilmann, 2010). The results of VEC model are presented in Table 7. 
Table 7: VEC Analysis Results

\begin{tabular}{|c|c|c|c|c|c|}
\hline \multicolumn{3}{|c|}{ Normalized Long-Term Analysis Results } & \multicolumn{3}{|c|}{ Short Term Analysis Results } \\
\hline Variable & Coefficient & t Statistics & Variable & Coefficient & t Statistics \\
\hline LnGOLD & 0.01 & 0.95 & $E C T_{t-1}$ & $-0.20 * * *$ & -5.29 \\
\hline LnOIL & $-0.01 * *$ & -2.34 & $\triangle L n T E T_{t-1}$ & $-0.35 * * *$ & -7.12 \\
\hline \multirow[t]{6}{*}{ Fixed Term } & 0.60 & 1.25 & $\triangle \operatorname{LnTET}_{t-2}$ & $-0.19 * * *$ & -4.19 \\
\hline & & & $\triangle L n G O L D_{t-1}$ & -0.0007 & -0.05 \\
\hline & & & $\triangle L n G O L D_{t-2}$ & 0.002 & 0.17 \\
\hline & & & $\Delta \operatorname{LnOIL}_{t-1}$ & -0.004 & -0.47 \\
\hline & & & $\Delta \operatorname{LnOIL}_{t-2}$ & 0.004 & 0.51 \\
\hline & & & Fixed Term & 0.0001 & 0.08 \\
\hline \multicolumn{6}{|c|}{ Diagnostic Tests } \\
\hline$R^{2}$ & \multicolumn{2}{|c|}{0.24} & $S S R$ & \multicolumn{2}{|c|}{0.005} \\
\hline$\overline{\boldsymbol{R}}^{2}$ & \multicolumn{2}{|c|}{0.23} & SEE & \multicolumn{2}{|c|}{0.003} \\
\hline$F$ & \multicolumn{2}{|c|}{22.45} & Log Likelihoo & \multicolumn{2}{|c|}{2060.61} \\
\hline
\end{tabular}

Note: $* *$ and $* * *$ indicate that the relevant coefficient is statistically reliable at $5 \%$ and $1 \%$ significance level, respectively. Critical table values for $\mathrm{t}$ test at $5 \%$ and $1 \%$ significance level are 1.96 and 2.57 , respectively.

According to the long-term results in Table 7, gold does not have a statistically significant effect on Tether while oil prices show a negative effect. The negative effects represent that there is a substitution relationship in between gold and Tether, therefore, these investment instruments are becoming alternative to each other.

In short-term analysis, the coefficient of error correction term $\left(E C T_{t-1}\right)$ of the model is negative and statistically significant. This shows that the error correction mechanism of the model works, short-term deviations among long-term cointegrating series are eliminated and the analysis become reliable. Hence, gold and oil have no statistically significant effect on Tether prices in the short term.

\subsection{Causality Test}

Because all series are found to be I(1), the causality relationships among the series are investigated by the Dolado and Lütkepohl (1996) causality test. Like Toda-Yamamoto (1995), the causality test of Dolado and Lütkepohl (1996) refers to the Toda and Yamamoto (1995) approach and applies to the level values of the series. In this respect, it is more powerful than Granger (1969) causality test (Senturk \& Akbaş, 2012). In the Dolado and Lutkepohl (1996) causality test, the lag enhanced VAR model $(p+1)$ is estimated by adding 1 to the optimal delay length $(p)$ in the VAR model. The Enhanced Wald (MWALD) test is applied to the p-lag VAR coefficient matrix (Cetin and Seker, 2013). The $H_{0}$ hypothesis of this test is that "there is no causal relationship from the first variable to the second variable". Now, the presence of causality relationships among the series are analyzed by using the Dolado and Lütkepohl (1996) causality test based on the optimal lag lengths presented in Table 2 . The results obtained are presented in Table 8 . 
Table 8: Causality Test Results

\begin{tabular}{|l|c|c|c|}
\hline \multicolumn{1}{|c|}{$\boldsymbol{H}_{\boldsymbol{0}}$ Hypothesis } & $\begin{array}{c}\text { Chi-Square } \\
\text { Statistics }\end{array}$ & $\begin{array}{c}\text { Probability } \\
\text { Value }\end{array}$ & Decision \\
\hline InGOLD $\rightarrow$ LnBIT & 0.45 & 0.92 & No \\
\hline LnBIT $\rightarrow$ LnGOLD & 1.75 & 0.62 & No \\
\hline LnOIL $\rightarrow$ LnBIT & $6.65^{*}$ & 0.08 & Exist \\
\hline LnBIT $\rightarrow$ LnOIL & 2.93 & 0.40 & No \\
\hline \hline InGOLD $\rightarrow$ LnTET & 1.60 & 0.90 & No \\
\hline LnTET $\rightarrow$ LnGOLD & 2.58 & 0.76 & No \\
\hline LnOIL $\rightarrow$ LnTET & 7.43 & 0.19 & No \\
\hline LnTET $\rightarrow$ LnOIL & 6.83 & 0.23 & No \\
\hline \hline InGOLD $\rightarrow$ LnETH & 1.61 & 0.65 & No \\
\hline LnETH $\rightarrow$ LnGOLD & 2.03 & 0.56 & No \\
\hline LnOIL $\rightarrow$ LnETH & 5.92 & 0.11 & No \\
\hline LnETH $\rightarrow$ LnOIL & $6.92^{*}$ & 0.07 & Exist \\
\hline InGOLD $\rightarrow$ LnLIT & 0.28 & 0.96 & No \\
\hline LnLIT $\rightarrow$ LnGOLD & $6.74 *$ & 0.08 & Exist \\
\hline LnOIL $\rightarrow$ LnLIT & 5.74 & 0.12 & No \\
\hline LnLIT $\rightarrow$ LnOIL & $7.24 *$ & 0.06 & Exist \\
\hline \hline LnGOLD $\rightarrow$ LnEOS & 5.81 & 0.12 & No \\
\hline LnEOS $\rightarrow$ LnGOLD & 1.21 & 0.75 & No \\
\hline LnOIL $\rightarrow$ LnEOS & 0.78 & 0.85 & No \\
\hline LnEOS $\rightarrow$ LnOIL & $7.67 *$ & 0.05 & Exist \\
\hline
\end{tabular}

Note: * indicates the presence of causality relationship at the $10 \%$ significance level from the first variable to the second variable in the relevant line.

Table 8 shows that there are unidirectional causality relationships with a $10 \%$ significance level from oil to Bitcoin, from Litecoin to Gold, from Ethereum, Litecoin and EOS to oil. The rate of $10 \%$ is a low level of validity in statistics and hence maybe neglected. In other words, it maybe concluded that there exist negligible relations among crypto coins and gold and oil.

\section{Conclusion}

Most popular five cryptocurrencies in this study are investigated if these cryptocurrencies show relations to changes in prices of oil and gold. Time series analysis is employed. Initially, the stationarity of the series is tested by using the $\mathrm{Ng}$ and Perron (2001) method and determined that all series are I(1). Then the existence of the cointegration relationship among the series is tested by the Johansen (1988) method and found that there exists a cointegration relationship only in between Tether and gold and oil prices. Later, the long and the short term analysis are conducted only for this crypto currency. The long and the short term analysis are performed by employing the VEC method and observed that only the increase in oil prices negatively affects the Tether prices. However, this effect is also very weak. When Brent crude oil prices increase by $1 \%$, the Tether prices decrease by $0.01 \%$. The existence of causality relationships among the series is investigated by the causality test of Dolado and Lutkepohl (1996) and determined that there are unidirectional causality relationships at a $10 \%$ significance level from Oil to Bitcoin, from Litecoin to Gold, from Ethereum, Litecoin and EOS to Oil. A $10 \%$ confidence level represents a weak validity in statistics. Therefore, the possible causalities can be neglected. Based on the empirical findings, it can be stated that there are negligible relations (minor) among cryptocurrencies and gold and oil. As a result, for now, investors may not need to consider cryptocurrencies in their portfolio choices. Cryptocurrencies have not yet become a substitute for gold and oil yet. 


\section{References}

Abeer ElBahrawy, Laura Alessandretti, Anne Kandler, Romualdo Pastor $\quad$ Satorras, Andrea Baronchelli

(2017)

Evolutionary dynamics of the cryptocurrency market. Research on Social Open Scientist., 4.

A. Cheung, E. Roca, J.-J. Su (2015). Crypto-currency bubbles: an application of the Phillips-Shi-Yu (2013) methodology on Mt. gox bitcoin prices, Applied Economics, 47, pp. 2348-2358

Bouoiyour, J., and R. Selmi (2015). What Does BitCoin Look Like? MPRA Paper No. 58091. Germany: University Library of Munich.

Buchholz, M., J. Delaney, J. Warren, and J. Parker (2012). Bits and Bets, Information, Price Volatility, and Demand for BitCoin, Economics 312." www.bitcointrading.com/pdf/bitsandbets.pdf.

Charles, A., Darne, O. and Tripier, F. (2018). Uncertainty and the Macroeconomy: Evidence from an Uncertainty Composite Indicator. Applied Economics, 50(10), 1093-1107.

Cetin, M. ve Seker, F. (2013). Dogrudan Yabancı Yatırımlar ve Ihracat Iliskisi: Gelismekte Olan Ulkeler Uzerine Bir Nedensellik Analizi. Eskisehir Osmangazi Universitesi IIBF Dergisi, 8(1), 121 - 142.

$\mathrm{CutCu}$, I. ve Kılıc, Y. (2018). Bitcoin Fiyatları ile Dolar Kuru Arasındaki Iliski: Yapısal Kırılmalı Zaman Serisi Analizi. Yonetim ve Ekonomi Araştırmaları Dergisi, 16(4), 349-366.

Dikmen, N. (2012). Ekonometri. (2. Bask1). Dora Yayınları, Bursa.

Dolado, J. L. and Lutkepohl, H. (1996). Making Wald Tests Work for Cointegrated VAR Systems. Econometric Reviews, 15, 369-386.

Elder, J. and Kennedy, P. E. (2001). Testing for Unit Roots: What Should Students Be Taught? Journal of Economic Education, Spring, 137-146.

Engle, R. F. and C. W. J. Granger (1987). Co-integration and Error Correction: Representation, Estimation and Testing. Econometrica, 55 , 251-276.

Granger, C. W. J. and Newbold, P. (1974). Spurious Regressions in Econometrics. Journal of Econometrics, 2, 111120.

Gulec, Ö. F., Çevik, E. ve Bahadır, N. (2018). Bitcoin ile Finansal Göstergeler Arasındaki İlişkinin İncelenmesi.

Kırklareli Üniversitesi İktisadi ve İdari Bilimler Fakültesi Dergisi, 7(2), 18-37.

G.P. Dwyer (2014). The economics of Bitcoin and similar private digital currencies. Journal of Financial Stability, 17 (2014), pp. 81-91

Heilmann, K. (2010). Stock Market Linkages - A Cointegration Approach. https://pdfs.semanticscholar.org/ae37/88c72e8613e7ce6f47b4d8d6e69a1012168a.pdf, (reached at 07.07.2019).

Hubrich, K., Lutkepohl, H. and Saikonen, P. (2001). A Review of Systems Cointegration Tests. Econometric Reviews, 20(3), 247-318.

Jamal Bouoiyour, Refk Selmi (2015). Bitcoin Price: Is It Really That New Round of Volatility can Be on Way? MPRA Paper 65580, University Library of Munich, Germany (2015), https://ideas.repec.org/p/pra/mprapa/65580.html

Johansen, S. (1988). Statistical Anaylsis of Cointegrating Vectors. Journal of Economic Dynamics and Control. 12, $231-254$.

Kesebilir, M. ve Gunceler, B. (2019). Kripto Para Birimlerinin Parlak Geleceği. Igdır Üniversitesi Sosyal Bilimler Dergisi, 17, 605-625.

Kristoufek, L. (2013). Bitcoin Meets Google Trends and Wikipedia: Quantifying the Relationship between Phenomena of the Internet Era." Scientific Reports 3 (3415): 1-7. doi:10.1038/srep03415.

Kremers, J. J., Ericsson, N. R. and Dolado, J. J. (1992). The Power of Cointegration Tests. https://www.bde.es/f/webbde/SES/Secciones/Publicaciones/PublicacionesSeriadas/DocumentosTrabajo/92/Fic h/dt_9218e.pdf, (reached at 08.07.2019).

Ng, S. and Perron, P. (2001). Lag Length Selection and the Construction of Unit Root Tests with Good Size and Power. Econometrica, 69(6), 1519 - 1554.

Ozturk, M. B., Arslan, H., Kayhan, T. ve Uysal, M. (2018). Yeni Bir Hedge Enstrumanı Olarak Bitcoin: Bitconomi. Ömer Halisdemir Universitesi Iktisadi ve Idari Bilimler Fakültesi Dergisi, 11(2), 217-232.

Phillips, P. C. B. and Perron, P. (1988). Testing for Unit Roots in Time Series Regression. Biometrika, 75, 335 - 346.

Sarkaya Icellioglu, C. ve Engin Ozturk, M. B. (2018). Bitcoin ile Secili Döviz Kurları Arasındaki İliskinin Arastırılması: 2013-2017 Dönemi için Johansen Testi ve Granger Nedensellik Testi. Maliye ve Finans Yazılarl, (109), 51-70.

Senturk, M. ve Akbas, Y. E. (2012). Finansal Aktif Fiyatları ve Borsa Getirisi Iliskisi: Turkiye Ornegi Uzerine Bir Uygulama. Finansal Araştırmalar ve Calışmalar Dergisi, 3(6), 41 - 53.

Tarı, R. (2012). Ekonometri. (8. Baskı). Umuttepe Yayınları, Kocaeli. 
Van Wijk, D. (2013). What can be expected from the BitCoin? Working Paper No. 345986. Rotterdam: Erasmus Rotterdam Universiteit.

\section{Appendix 1: Graphs of the Data Raw Data, Ln Data and Differenced Ln Data}

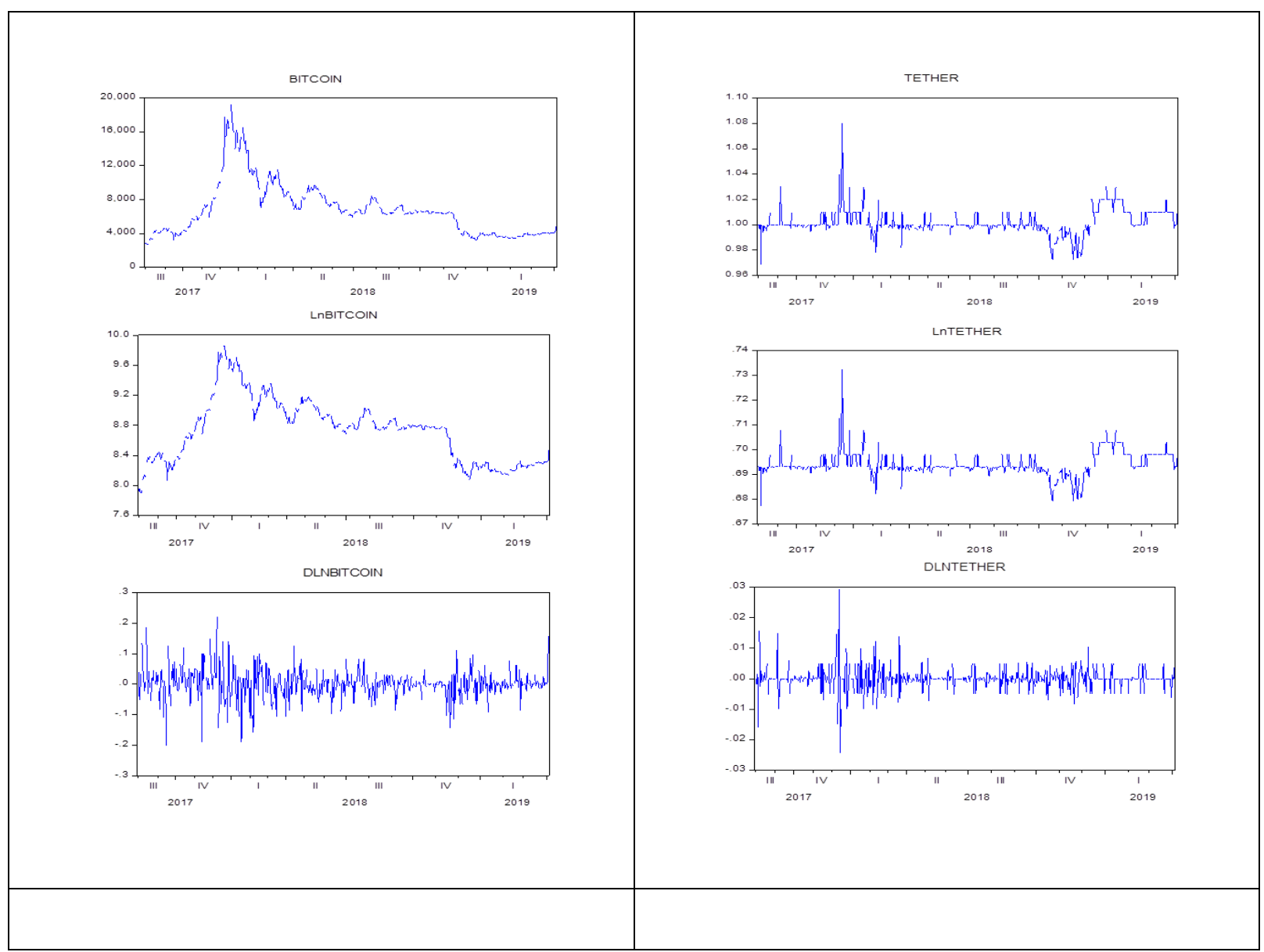




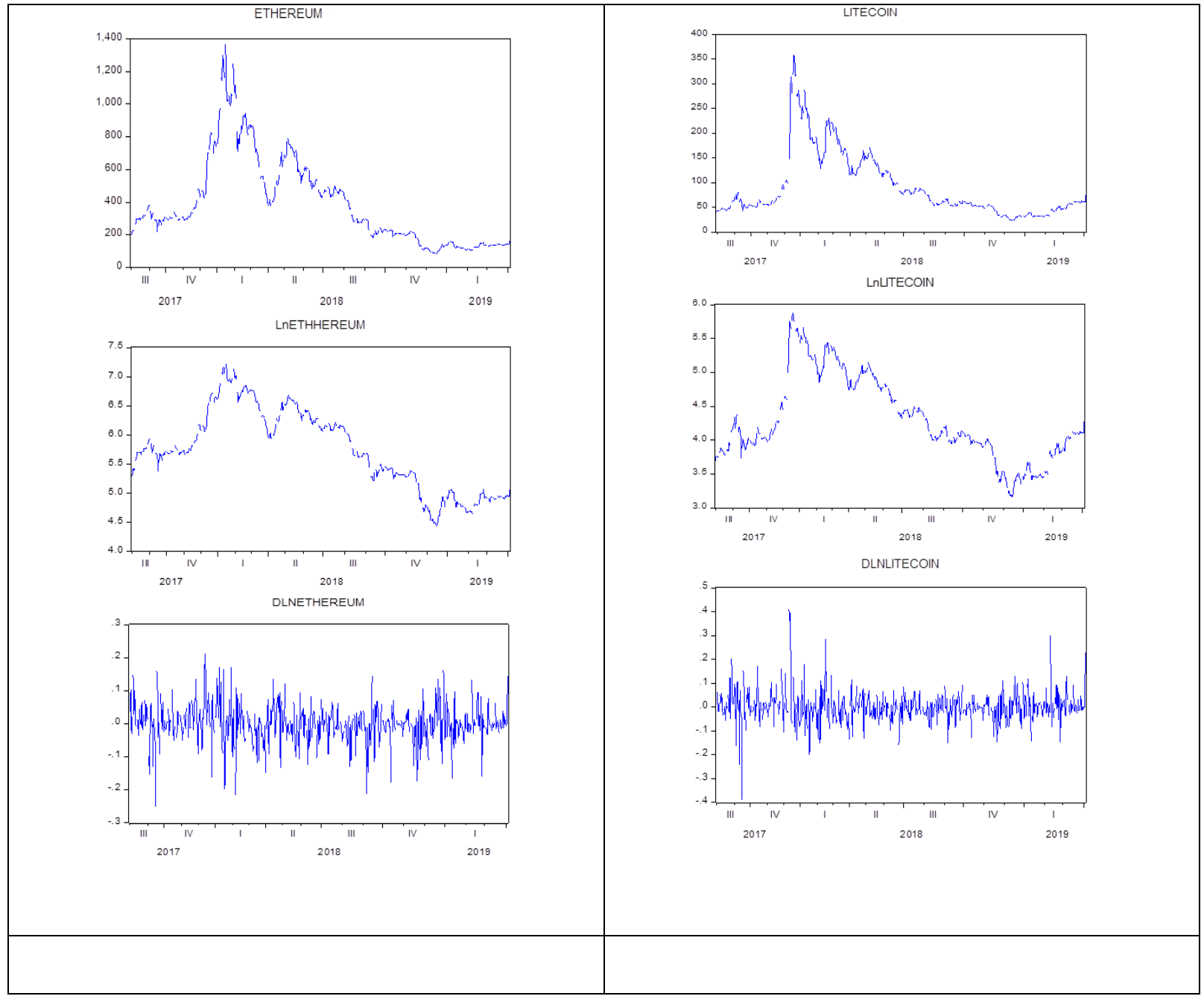




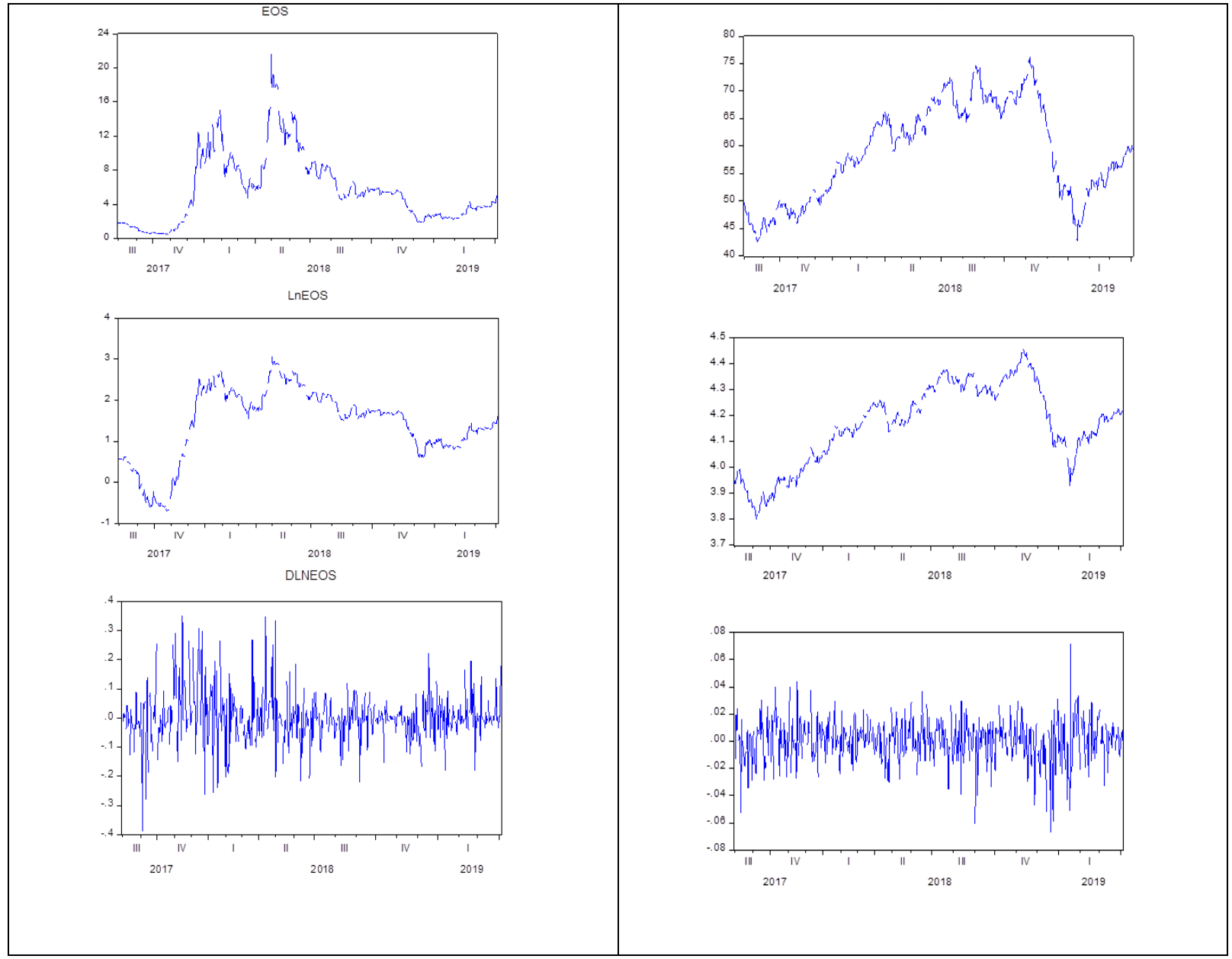

Appendix 2: Graphs of Inverse Characteristic Roots Concerning Stability of VAR Models with Determined Optimum Lag Length

Bitcoin

Inverse Roots of AR Characteristic Polynomial

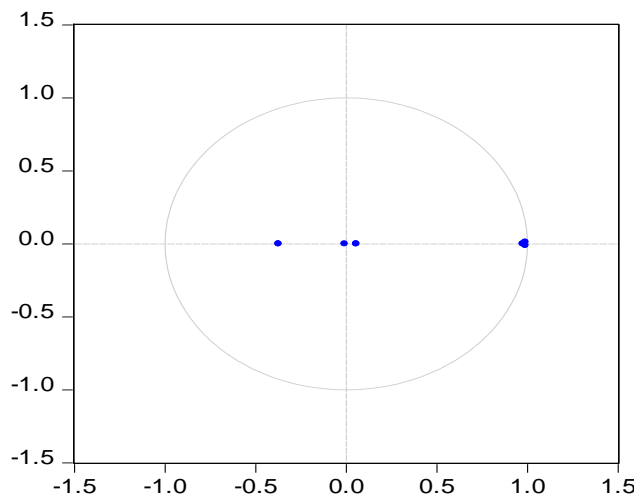

Tether

Inverse Roots of AR Characteristic Polynomial

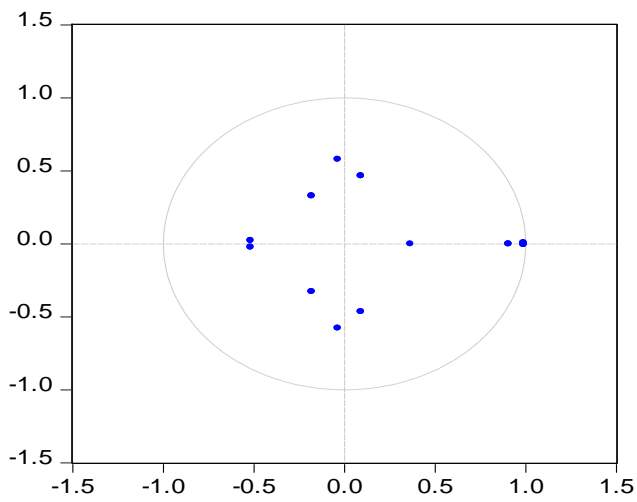


Ethereum

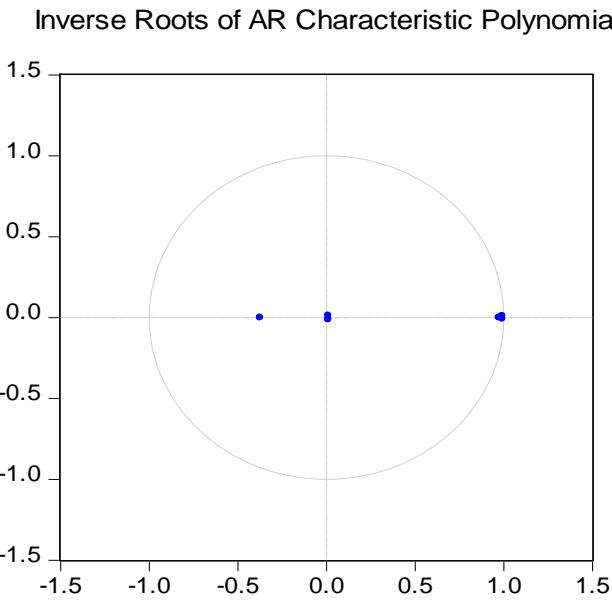

Litecoin

Inverse Roots of AR Characteristic Polynomial

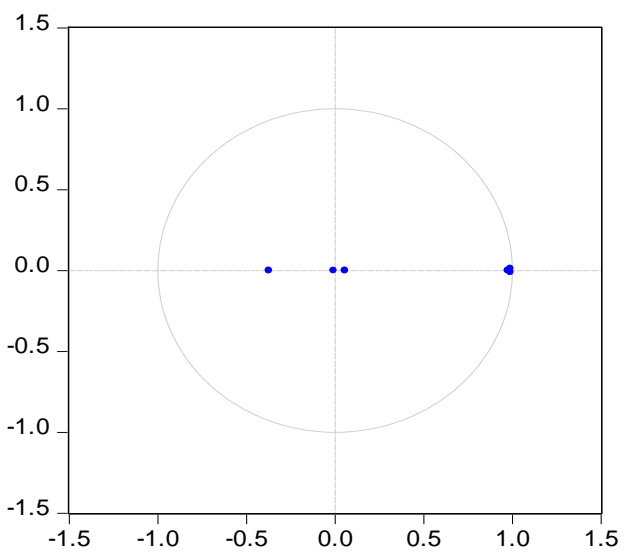

\section{EOS}

Inverse Roots of AR Characteristic Polynomial

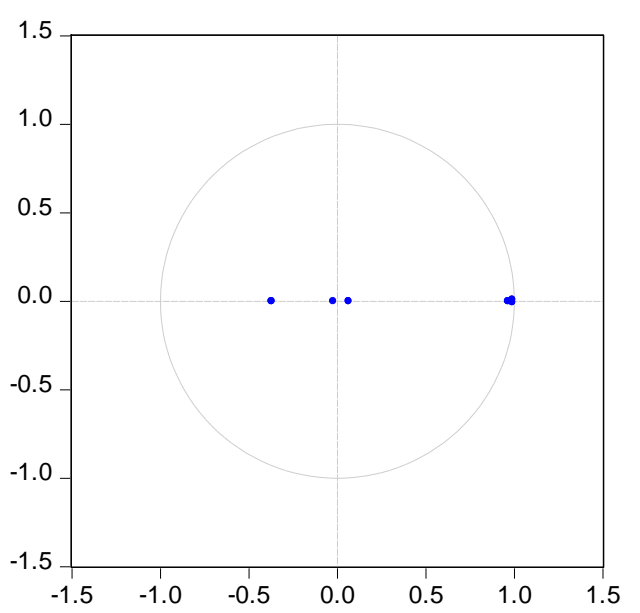

